\title{
Report TEI-799
}

I N T E I M REPORT ON GEOLOG I C

U. S. GEOLOGICAL SUR Field Librory

INVESTIGATIONS OF THE U I $2 \mathrm{~b}$ Bubuguerque, New Merico

TUNNEL SYSTE, NEVADA TEST SITE,

N Y E C O U N T Y, N E V A D A

By D. D. Dickey and W. L. Emerick

UNITED STATES DEPARTMENT OF THE INTERIOR

GEOLOGICAL SURVEY 



\section{UNITED STATES \\ DEPARTMEITT OF THE INTERIOR \\ GEOLOGICAL SURVEY \\ Washington 25, D. C.}

November 8, 1961

Mr. James E. Reeves

Assistant Manager for Test Operations

Albuquerque Operations Office

U. S. Atomic Energy Commission

P. O. Box 5400

Albuque rque, New Mexico

Dear Mr. Reeves:

Transmitted, herewith, are ten copies of TEI-799, "Interim report on geologic investigations of the Ul2b tunnel system, Nevada Test Site, Nye County, Nevada," by D. D. Dickey and W. L. Emerick, September 1961.

We plan to release this report to the public in the open files.

Sincerely yours,

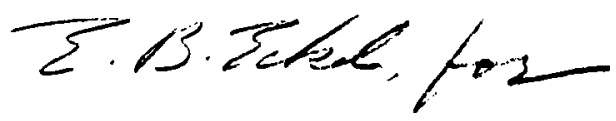

V. E. McKelvey

Assistant Chief Geologist

Interagency Programs and

Supporting Activities 


\title{
UNITED STATES DEPARTMENT OF THE INTERIOR \\ GEOLOGICAL SURVEY
}

\begin{abstract}
INTERIM REPORT ON GEOLOGIC INVESTIGATIONS OF THE UIZb
TUNNEL SYSTEM, NEVADA TEST SITE, NYE COUNTY, NEVADA*
\end{abstract}

By

D. D. Dickey and W. L. Emerick

September 1961

This report is preliminary

and has not been reviewed

for conformity with Geological

Survey standards.

*Prepared on behalf of the U. S. Atomic Energy Commission. 
Albuquerque Operations Office (J. E. Reeves) Division of Military Application, Washington (J. S. Kelly)-.-.- 2 Division of Raw Materials, Washington (R. D. Nininger)-...... 2 Division of Research, Washington (D. R. Miller) Grand Junction Operations Office-..............-..- I

Las Vegas Area Office (F. W. Hőhner) ......... 2

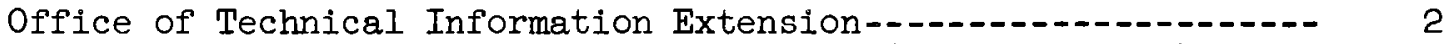
Chemistry Division, Argonne National Lab。(W. M. Manning)...... I 1 Chemical Tech。Div., Oak Ridge Natl. Lab. (W. E. Clark)-......- 1 Engineer Research \& Development Lab., Ft. Belvoir, Va. (Chief, Special Projects Branch)-_-.... 1 Health Physics Div., Oak Ridge Natl. Lab。(F. L. Parker) -...... 4 Lawrence Radiation Lab。, Livermore (G.W. Johnson) -........... 10 Lawrence Radiation Lab., Mercury (J. Olsen) -.................. 3 Los Alamos Scientific Laboratory (J.H. Hall) Los Alamos Scientific Laboratory (R. W. Newman)-...-...-. I Sandia Corp., Albuquerque (D。B. Shuster) .......... 2 Stanford Research Institute, Menlo Park (R. M. Foose)......... I U.S. Naval Radiological Defense Lab., San Francisco (N. E. Ballou) 


$$
\text { USGS - TEI-799 }
$$

Distribution - USGS

No. of copies

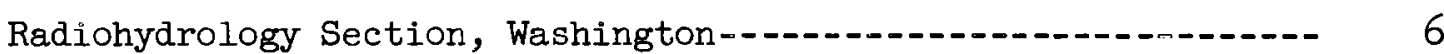

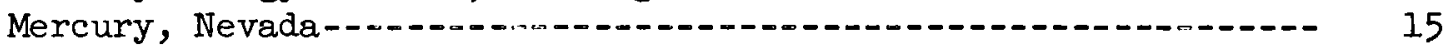

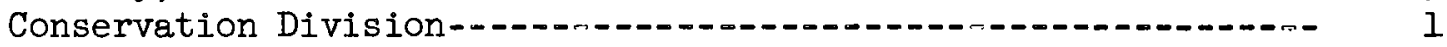

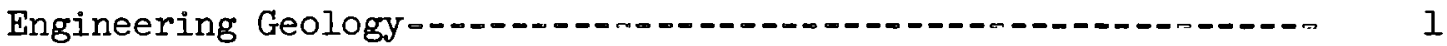

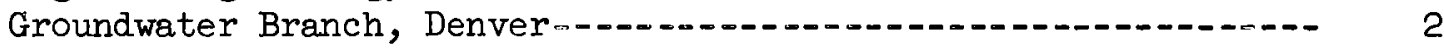

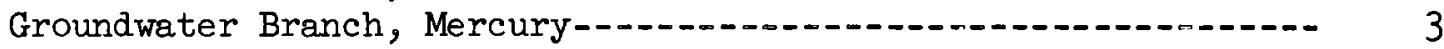

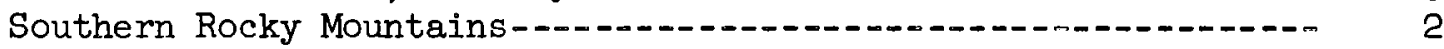

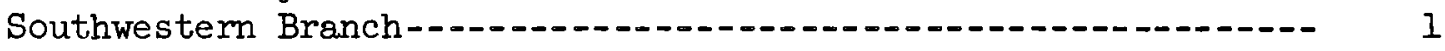

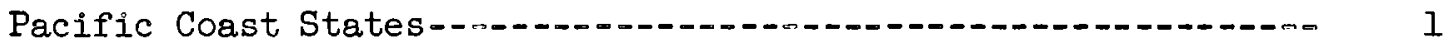

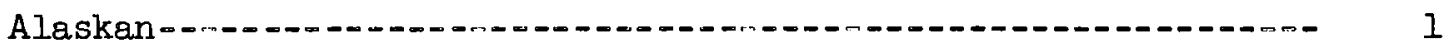

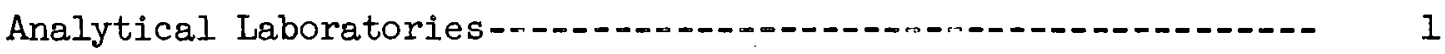

Library--_- 3

Special Projects-....... 30

Geologic Division-...- 6 
CONTERTS

Page

Introduction- 2

Geology

References- 12

\section{ILLUSTRATIONS}

Figure 1. Index map showing the tunnel area, Nevada Test Site, Nye County, Nevada-n

2. Geologic map and sections of the Ul2b tunnel

system, Nevada Test Site, Nye County, Nevada-.-.- In pocket

\section{TABLES}

Table 1. Chemical analyses of tuff from the Ul2b tunnel system, Nevada Test Site, Nye County, Nev.-..---

2. Semiquantitative spectrographic analyses of tuff from the Ul2b tunnel system, Nevada Test Site, Nye County, Nev. 
INTERIM REPORT ON GEOLOGIC INVESTIGATIONS OF THE UI2b TUNNEL SYSTEM, NEVADA TEST SITE, NYE COUNTY, NEVADA

By D. D. Dickey and W. L. Emerick

- INTRODUCTION

The map and tables of this report are being transmitted at this time to provide interested parties with a summary of the geology of the $U 12 b$ tunnel system, which was constructed to provide access to underground test sites. This report contains part of the geologic information obtained from investigations conducted by the U.S. Geological Survey, on behalf of the U.S. Atomic Energy Commission, to determine the geologic environment of the underground test sites.

The U12b tunnel system, which has been driven southwestward beneath a prominent topographic feature called Rainier Mesa in the northern part of the Nevada Test Site (fig. 1), consists of a main tunnel 2,500 feet long with eight shorter side tunnels designated U12b.01, U12b.02, U12b.03, U12b.04, U12b.05, Rainier, U12b.07, and Ul2b.09 (fig.2)。Detailed reports on the geology of tunnels Ul2b.01 (Diment and others, 1959b), U12b.02 (Diment and others, 1958), U12b.03 and U12b.04 (Diment and others, 1959a), and Rainier (Gibbons, 1958) have been released in the TEM and TEI series and have been placed on open file. Detailed reports on the U1.2b.07 and U12b.09 tunnels are to be issued in the near future. This report, which summarizes the geology of the tunnel system, includes the data contained in the published and unpublished reports. 


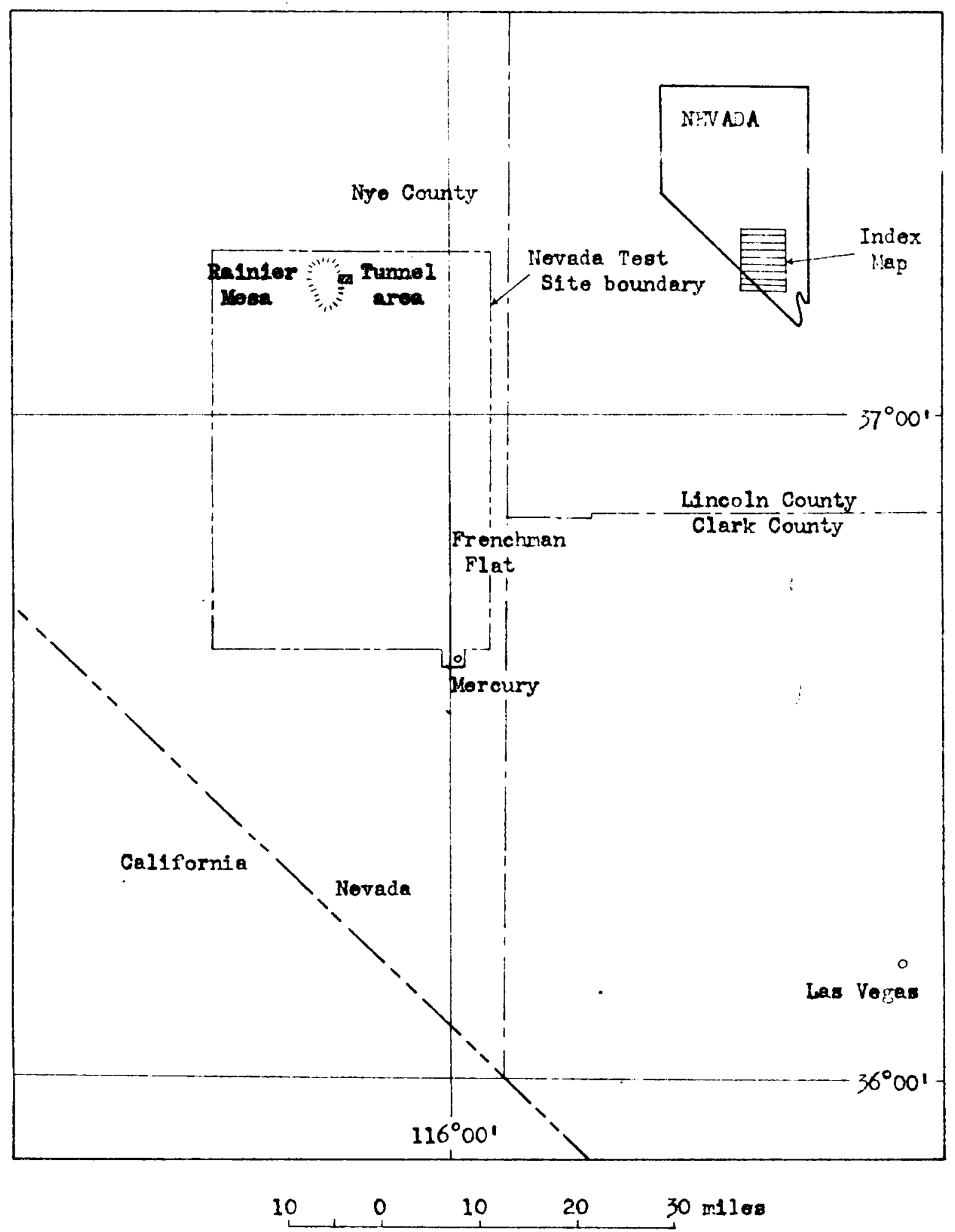

Figure 1.-Inder mp showling the tunnel area, Hevada Test S1to, Hyo 


\section{GEOLOGY}

The U12b tunnel system penetrates tuffaceous rocks of the Oak Spring Formation of Miocene(?) or younger age. In the Rainier Mesa area the Oak Spring Formation ranges in thickness from 1,900 feet to more than 3,000 feet and rests disconformably on a surface of moderate to considerable relief cut into rocks of Paleozoic age. The Oak Spring Formation in the tunnel area has been separated by Hinrichs and Orkild (1961) into four members which are in descending order: Rainier Mesa, Survey Butte, Grouse Canyon, and lower. The lower member in the tunnel area is further subdivided into Tunnel Beds 1 through 4. The members are equivalent to the map units 1 through 8 of the Oak Spring Formation of Hansen and Lemke (1957) as follows: Rainier Mesa is equivalent to unit 8; Survey Butte is equivalent to unit 7; Grouse Canyon, upper part, is equivalent to unit 6; Grouse Canyon, lower part, is equivalent to unit 5; and lower (Tunnel Beds, 1 through 4) is equivalent to units 1 through 4. Tunnel Beds, 1 through 4, are also equivalent to the Tunnel Beds 1 through 4 of McKeown and Dickey (1961).

The Ul2b tunnel system penetrates rocks of the lower part of the Survey Butte Member, the upper and the lower parts of the Grouse Canyon Member, and Tunnel Bed 4 of the lower member. Gibbons (1958) subdivided the rocks into subunits designated by capital letters $J$ through $\mathrm{Z}$; this nomenclature has been used in compilation of the geologic map, figure 2 , and in tables 1 and 2. Subunit $J$ is in 
Table 1.--Chemical analyses of tuff from the U12b tunnel system, Nevada Test Site, Nye County, Nev.

[Chemical analyses by methods similar to those described by Shapiro and Brannock (1956). Analyses by Paul L. D.

Elmore, Samuel D. Botts, Ivan H. Barlow, Gillison Chloe, Marvin D. Mack, and Herman H. Thomas.]

\begin{tabular}{|c|c|c|c|c|c|c|}
\hline $\begin{array}{l}\text { Sample } \\
\text { number }\end{array}$ & B23 & B29 & $\mathrm{B} 233$ & $\mathrm{~B} 234$ & $\mathrm{~B} 235$ & B237 \\
\hline $\begin{array}{l}\text { Lithologic } \\
\text { subunit-- }\end{array}$ & ${ }^{T s} s_{R}$ & ${ }^{T S} S_{S}$ & ${ }^{T} \mathrm{~s}_{\mathrm{S}}$ & $\mathrm{Ts}_{\mathrm{S}}$ & ${ }^{\mathrm{TS}} \mathrm{S}$ & ${ }^{\mathrm{T}} \mathrm{s}_{\mathrm{S}}$ \\
\hline $\mathrm{SiO}_{2}$ & 61.30 & 66.80 & 64.50 & 66.20 & 66.10 & 70.20 \\
\hline $\mathrm{Al}_{2} \mathrm{O}_{3}$ & 15.2 & 12 & 13.1 & 12.4 & 12.6 & 10.8 \\
\hline $\mathrm{Fe}_{2} \mathrm{O}_{3}$ & 3.6 & 2.9 & 3.1 & 3.1 & 3.1 & 2.2 \\
\hline $\mathrm{FeO}$ & .1 & .07 & .1 & .06 & .07 & .07 \\
\hline $\mathrm{MgO}$ & 1 & .73 & .93 & .78 & .82 & .81 \\
\hline $\mathrm{CaO}$ & 2.3 & 2.1 & 1.9 & 2 & 2.2 & 2.2 \\
\hline $\mathrm{Na}_{2} \mathrm{O}$ & 2.2 & .97 & 1.1 & 1.1 & 1.1 & .77 \\
\hline $\mathrm{K}_{2} \mathrm{O}$ & 5.2 & 2.3 & 2.8 & 2.6 & 2.7 & 1.9 \\
\hline $\mathrm{H}_{2} \mathrm{O}$ & & & & & & \\
\hline $\mathrm{H}_{2} \mathrm{O}+$ & 4.6 & 5.3 & 5.9 & 5.2 & 5.6 & $5.7^{\circ}$ \\
\hline $\mathrm{H}_{2} \mathrm{O}-$ & 3.6 & 6 & 6 & 6 & 5.7 & 5.6 \\
\hline $\mathrm{TiO}_{2}$ & .65 & .28 & .26 & .31 & .3 & .3 \\
\hline $\mathrm{P}_{2} \mathrm{O}_{5}$ & .2 & .04 & .01 & .02 & .02 & .03 \\
\hline $\mathrm{MnO}$ & .16 & .09 & .13 & .1 & .13 & .08 \\
\hline $\mathrm{CO}_{2}$ & .13 & .14 & .12 & .14 & .11 & .14 \\
\hline$\stackrel{\text { Sum }}{\text { (rounded) }}$ & 100 & 100 & 100 & 100 & 101 & 101 \\
\hline
\end{tabular}


Table 1. - Chemical analyses of tuff from the U12b tunnel system, Nevada Test Site, Nye County, Nev. --Continued

\begin{tabular}{|c|c|c|c|c|c|c|}
\hline $\begin{array}{l}\text { Sample } \\
\text { number } \ldots . . .\end{array}$ & B210 & B232 & B236 & B238 & B2500A & B2500B \\
\hline $\begin{array}{l}\text { Lithologic } \\
\text { subunit-- }\end{array}$ & $\mathrm{Ts}_{\mathrm{T}}$ & $\mathrm{Ts}_{\mathrm{T}}$ & $\mathrm{Ts}_{\mathrm{T}}$ & $\mathrm{Ts}_{\mathrm{T}}$ & $\mathbb{T s}_{\mathrm{W}}$ & ${ }^{T s} s_{x}$ \\
\hline $\mathrm{SiO}_{2}$ & 69.20 & 66.30 & 67.20 & 70.10 & 67.20 & 64.50 \\
\hline $\mathrm{Al}_{2} \mathrm{O}_{3}$ & 1.0 & 12.3 & 12.5 & 10.9 & 14.1 & 15.3 \\
\hline $\mathrm{Fe}_{2} \mathrm{O}_{3}$ & 2 & 2.7 & 3 & 2.1 & 1.2 & 2.3 \\
\hline $\mathrm{FeO}$ & .06 & .03 & .17 & .05 & .32 & .63 \\
\hline MgO & .9 & .75 & .75 & .77 & .62 & .89 \\
\hline $\mathrm{CaO}$ & 1.8 & 1.9 & 1.7 & 2.4 & 1.6 & 2.5 \\
\hline $\mathrm{Na}_{2} \mathrm{O}$ & .48 & 1.2 & 1.01 & .88 & 2.6 & 3.2 \\
\hline $\mathrm{K}_{2} \mathrm{O}$ & 2.1 & 2.9 & 2.8 & 2 & 4.3 & 4.1 \\
\hline $\mathrm{H}_{2} \mathrm{O}$ &.- & 8 & & $-\infty-\infty$ & 7.7 & 5.9 \\
\hline $\mathrm{H}_{2} \mathrm{O}+$ & 6.7 & 6.2 & 5.6 & 5.3 & $\ldots$ & -..- \\
\hline $\mathrm{H}_{2} \mathrm{O}-$ & 6.2 & 5.6 & 5.4 & 5.5 & $\ldots$ & ---- \\
\hline $\mathrm{TiO}_{2}$ & .1 & .24 & .26 & .35 & .19 & .42 \\
\hline $\mathrm{P}_{2} \mathrm{O}_{5}$ & 0 & 0 & .01 & .12 & .07 & .13 \\
\hline MnO & .09 & .13 & .13 & .08 & .06 & .09 \\
\hline $\mathrm{CO}_{2}$ & .18 & .11 & .22 & .12 & .05 & .05 \\
\hline $\begin{array}{c}\text { Sum } \\
\text { (rounded) }\end{array}$ & 100 & 100 & 101 & 101 & 100 & 100 \\
\hline
\end{tabular}


Table 1.--Chemical analyses of tuff from the Ul2b tunnel system,

Nevada Test Site, Nye County, Nev。--Continued

\begin{tabular}{|c|c|c|c|c|c|c|}
\hline $\begin{array}{l}\text { Sample } \\
\text { number } \ldots---\end{array}$ & B2500C & B250OD & $\mathrm{B} 2500 \mathrm{E}$ & $\mathrm{B} 2500 \mathrm{G}$ & $\mathrm{B} 2500 \mathrm{H}$ & $\mathrm{B} 2500 \mathrm{~F}$ \\
\hline $\begin{array}{l}\text { Lithologic } \\
\text { subunit--- }\end{array}$ & ${ }^{\mathrm{Ts}} \mathrm{Y}_{\mathrm{Y}}$ & ${ }^{T s_{Y}}$ & $\mathrm{Ts}_{\mathrm{Z}}$ & $\mathrm{Ts}_{\mathrm{Z}}$ & $\mathrm{Ts}_{\mathrm{Z}}$ & $\begin{array}{l}\text { Fault } \\
\text { zone }\end{array}$ \\
\hline $\mathrm{SiO}_{2}$ & 69.20 & 67.90 & 69.40 & 72.60 & 70.80 & 72.10 \\
\hline $\mathrm{Al}_{2} \mathrm{O}_{3}$ & 13.4 & 13.7 & 12.4 & 11.6 & 12.3 & 10.3 \\
\hline $\mathrm{Fe}_{2} \mathrm{O}_{3}$ & 1.3 & 1.6 & 1 & 1 & 1.1 & 1 \\
\hline FeO & .40 & .6 & .09 & .11 & .16 & .11 \\
\hline $\mathrm{MgO}$ & .36 & .63 & .66 & .28 & .39 & .64 \\
\hline $\mathrm{CaO}$ & 1.3 & 1.6 & 1.1 & 1 & 1.3 & 1.7 \\
\hline $\mathrm{Na}_{2} \mathrm{O}$ & 2.8 & 2.7 & 1.9 & 2.2 & 2.4 & 1.2 \\
\hline $\mathrm{K}_{2} \mathrm{O}$ & 4.4 & 4.2 & 4.2 & 4.2 & 4.2 & 2.3 \\
\hline $\mathrm{H}_{2} \mathrm{O}$ & 6.2 & 6.4 & 9.4 & 6.6 & 6.7 & 10 \\
\hline $\mathrm{H}_{2} \mathrm{O+}$ & - & & & & & $\ldots$ \\
\hline $\mathrm{H}_{2} \mathrm{O}-$ & & & & & & $---n$ \\
\hline $\mathrm{TiO}_{2}$ & .2 & $\cdot 3$ & .12 & .11 & .16 & .12 \\
\hline $\mathrm{P}_{2} \mathrm{O}_{5}$ & .06 & .08 & .03 & .02 & .12 & .03 \\
\hline $\mathrm{MnO}$ & .06 & .1 & .04 & .06 & .06 & .06 \\
\hline $\mathrm{CO}_{2}$ & .05 & .05 & .05 & .05 & .05 & .05 \\
\hline $\begin{array}{c}\text { Sum } \\
\text { (rounded) }\end{array}$ & 100 & 100 & 100 & 100 & 100 & 100 \\
\hline
\end{tabular}


Table 2. - - Semiquant1tative spectrographic analyses of tuff from the U12b tunnel system, Nevada Test Site, Nye County, Nev.

[Semlquantitative spectrographic analyses by Nancy M. Conklin and John C. Hamilton. d, barely detected and concentration uncerta1n. 0 , looked for but not detected. $\cdots$, not looked for.

Looked for but not found: $\mathrm{Ag}, \mathrm{As}, \mathrm{Au}, \mathrm{B}, \mathrm{B1}, \mathrm{Cd}, \mathrm{Co}, \mathrm{By}, \mathrm{Er}, \mathrm{Fu}, \mathrm{Gd}, \mathrm{Ge}, \mathrm{Hf}, \mathrm{Bg}, \mathrm{Ho}, \mathrm{In}, \mathrm{Ir}, \mathrm{Lt}, \mathrm{Lu}, \mathrm{Os}, \mathrm{Pd}, \mathrm{Pr}, \mathrm{Pt}, \mathrm{Re}$, $\mathrm{Rh}, \mathrm{Ru}, \mathrm{Sb}, \mathrm{Sn}, \mathrm{Sm}, \mathrm{Ta}, \mathrm{Tb}, \mathrm{Te}, \mathrm{Th}, \mathrm{Tl}, \mathrm{Tm}, \mathrm{U}, \mathrm{W}, \mathrm{Zn}$.

Figures are reported to the nearest number in the serles $7,3,1.5,0.7,0.3,0.15$, etc., in percent. These numbers represent midpolnts of group data on a geometric scale. Comparisons of this type of semiquantitative result with data obtained by quantitative methods, either chemfcal or spectrographic, show that 60 percent of the quant1tat1ve values fall within the assigned semiquantitative groups.]

\begin{tabular}{|c|c|c|c|c|c|c|c|c|c|c|c|c|c|c|}
\hline $\begin{array}{l}\text { Sample } \\
\text { number--- }\end{array}$ & $\mathrm{B16}$ & B18 & B19 & B23 & B25 & B29 & $\mathrm{B} 233$ & B234 & B235 & B237 & B210 & $B 232$ & B236 & B238 \\
\hline $\begin{array}{l}\text { L1thologic } \\
\text { subunit- }\end{array}$ & $\mathrm{Ts}_{\mathrm{Q}}$ & $T s_{R}$ & ${ }^{T s_{R}}$ & $\mathrm{Ts}_{\mathrm{R}}$ & $\mathrm{Ts}_{\mathrm{R}}$ & $\mathrm{Ts}_{\mathrm{S}}$ & ${ }^{T} s_{S}$ & ${ }^{T} s_{S}$ & ${ }^{T s} s_{S}$ & ${ }^{\mathrm{Ts}} \mathbf{S}_{\mathrm{S}}$ & $\mathrm{Ts}_{\mathrm{T}}$ & $\mathrm{Ts}_{\mathrm{T}}$ & $\mathrm{Ts}_{\mathrm{T}}$ & $\mathrm{Ts}_{\mathrm{T}}$ \\
\hline $\mathrm{Ba}$ & .07 & .15 & .15 . & .3 & .3 & .03 & .015 & .015 & .03 & .015 & .007 & .015 & .015 & .015 \\
\hline $\mathrm{Be}$ & .0007 & .0003 & .0007 & .00015 & .00015 & .0007 & .0007 & .0007 & .0003 & .0003 & .0007 & .0007 & .0007 & .0003 \\
\hline $\mathrm{Ce}$ & .03 & a & d & .03 & $d$ & .03 & .03 & $d$ & $d$ & 0 & d & $\mathrm{d}$ & $d$ & 0 \\
\hline $\mathrm{Cr}$ & .00015 & .00015 & .00015 & $d$ & 0 & .0003 & .0007 & .0007 & .0007 & .0003 & .00015 & .0007 & .0007 & .00015 \\
\hline $\mathrm{Cs}$ & -- & -- & -- & -- & -- & -- & -- & -- & -- & - & -- & -- & -- & -- \\
\hline $\mathrm{Cu}$ & .0003 & .0003 & .0003 & .0007 & .0003 & .0015 & .0007 & .0007 & .0007 & .0007 & .0007 & .0007 & .0007 & .0007 \\
\hline $\mathbf{F}$ & $\cdots$ & -- & -- & - & -- & -- & -- & -- & -- & -- & - & -- & $=-$ & - \\
\hline $\mathrm{Ga}$ & .0015 & .003 & .0015 & .003 & .003 & .003 & .0015 & .0015 & .0015 & .0007 & .0015 & .0015 & .0015 & .0007 \\
\hline La & .015 & .007 & .007 & .03 & .015 & .015 & .015 & .015 & .007 & .003 & .003 & .007 & .015 & .003 \\
\hline Mo & 0 & 0 & 0 & .0007 & 0 & 0 & 0 & 0 & 0 & 0 & 0 & 0 & 0 & 0 \\
\hline
\end{tabular}


Table 2.--Semiquant1tative spectrographic analyses of tuff from the U12b tunnel system, Nevada Test Site, Nye County, Nev. --Continued

\begin{tabular}{|c|c|c|c|c|c|c|c|c|c|c|c|c|c|c|}
\hline $\begin{array}{l}\text { Sample } \\
\text { number--- }\end{array}$ & B16 & B18 & B19 & B23 & B25 & B29 & B233 & B234 & B235 & B237 & B210 & B232 & B236 & B238 \\
\hline $\begin{array}{l}\text { Lithologic } \\
\text { subunit-- }\end{array}$ & $\mathrm{Ts}_{Q}$ & $\mathrm{Ts}_{\mathrm{R}}$ & ${ }^{\mathrm{Tg}} \mathrm{R}_{\mathrm{R}}$ & $\mathrm{Ts}_{\mathrm{R}}$ & $\mathrm{Ts}_{\mathrm{R}}$ & ${ }^{T} \mathbf{s}_{\mathrm{S}}$ & ${ }^{T s} s_{S}$ & ${ }^{\mathrm{Ts}} \mathrm{s}$ & $\mathrm{Ts}_{\mathrm{S}}$ & $\mathrm{Ts}_{\mathrm{S}}$ & $\mathrm{Ts}_{\mathrm{T}}$ & $\mathrm{Ts}_{\mathrm{T}}$ & $\mathrm{Ts}_{\mathrm{T}}$ & $\mathrm{Ts}_{\mathrm{T}}$ \\
\hline $\mathrm{Nb}$ & .003 & .0015 & .0015 & .003 & .0015 & .007 & .003 & .003 & .003 & .0015 & .003 & .003 & .003 & .0015 \\
\hline $\mathrm{Nd}$ & .015 & $\mathrm{~d}$ & d & .015 & .015 & .015 & .015 & .015 & $\mathrm{~d}$ & 0 & 0 & d & .015 & 0 \\
\hline N1 & 0 & 0 & 0 & 0 & .0003 & 0 & 0 & 0 & 0 & 0 & 0 & 0 & 0 & 0 \\
\hline $\mathrm{Pb}$ & .0015 & d & $\mathrm{d}$ & .0015 & .0015 & .003 & .0015 & .0015 & .0015 & 0 & .003 & .0015 & .0015 & 0 \\
\hline $\mathrm{Rb}$ & -- & -- & -- & -- & -- & -- & -- & -- & -- & -- & -- & -- & -- & -- \\
\hline Sc & .0015 & .0015 & .0015 & .003 & .0015 & d & .0015 & .0007 & .0007 & 0 & $\cdot 0$ & .0007 & .0007 & 0 \\
\hline $\mathrm{Sr}$ & .015 & .03 & .03 & .03 & .03 & .015 & .015 & .015 & .015 & .015 & .015 & .015 & .015 & .015 \\
\hline$v$ & .0015 & .0015 & .0015 & .0015 & .0015 & .0015 & .0015 & .0015 & .003 & .0015 & .0015 & .0015 & .0015 & .0015 \\
\hline$Y$ & .003 & .003 & .003 & .003 & .003 & .007 & .003 & .003 & .003 & .003 & .003 & .003 & .003 & .003 \\
\hline Yo & .0003 & .0003 & .0003 & .0007 & .0007 & .015 & .0003 & .0003 & .0003 & .0003 & .0003 & .0003 & .0003 & .0003 \\
\hline $\mathrm{Zr}$ & .03 & .015 & .015 & .07 & .03 & .15 & .03 & .03 & .03 & .015 & .03 & .03 & .03 & .015 \\
\hline
\end{tabular}


Tunnel Bed 4 of the lower member, subunits $K$ and $L$ are in the lower part of the Grouse Canyon Member, subunits $M$ through $O$ are in the upper part of the Grouse Canyon Member, and the remaining subunits, $\mathrm{P}$ through $\mathrm{Z}$, are in the lower part of the Survey Butte Member.

The geology of the Ul2b tunnel is shown on figure 2. Some of the stratigraphic correlations shown on the geologic map require qualification. The principal area, in which the nomenclature of the rocks is in doubt, is on the right wall at the end of the Ul2b main tunnel where there is exposed for only a short distance a tuff sequence that resembles the subunits $W, X, Y$, and $Z$ found in other parts of the tunnel system. In this area, however, the thicknesses of the subunits vary widely, and the contact at the base of subunit $\mathrm{Z}$, which is distinctively erosional elsewhere, is conformable. Because of the many variations in lithology and thickness of the tuff units exposed in the tunnel system, and because of the limited exposure, the stratigraphic position of the tuffs at the end of the $\mathrm{U} 12 \mathrm{~b}$ tunnel was not resolved.

The major structures mapped in the tunnel system are a southwest-trending syncline and antjcline, and a northwest-trending fault. (See fig. 2.) The syncline which crosses the Ul2b.03, Rainier, main $\mathrm{Ul} 2 \mathrm{~b}$, and $\mathrm{Ul} 2 \mathrm{~b} .09$ tunnels has an average strike of S. $85^{\circ}$ W. and plunges $2^{\circ} \mathrm{SW}$. The anticline crosses the Ul2b.07 tunnel and strikes and plunges in the same general direction as the adjacent syncline. The syncline and anticline were mapped on the 
surface by Gibbons and others (1960). Beds dip as much as $28^{\circ}$ toward the axis of the syncline. The major fault in the tunnel system has an average strike of $\mathrm{N} .30^{\circ} \mathrm{W}$. and dips steeply southwest. The beds have been downdropped more than 15 feet on the southwest side. The fault was intersected at $25+00$ in the main U1.2b tunnel and near the first curve in the U12b.09 tunnel; its probable continuation was mapped near the end of the U12b.04 tunnel (fig.2). The other faults mapped in the tunnel strike N. $20^{\circ}$ W. to $N .80^{\circ}$ W., dip steeply and have displaced the rocks as much as 4 feet vertically.

Shown on figure 2 are joint diagrams that graphically summarize the attitudes of the joints measured in the section of tunnel enclosed by brackets. The average strike and dip and the relative abundance of joints for each joint set can be determined from the diagrams. The chemical and spectrographic analyses of tuffs from the Ul2b tunnels that were not available in existing reports are presented in tables 1 and 2. Table 1 gives the oxide contents of the major constituents, and table 2 reports the minor element contents as determined by semiquantitative spectrographic analyses. 
REFERENCES

Diment, W. H., Wilmarth, V. R。, McKeown, F. A., Dickey, D. D., and others, 1958, Geological Survey investigations in the U12b.02 tunnel, Nevada Test Site: U.S. Geol. Survey TEM-224, issued by U.S. Atomic Energy Comm. Tech. Inf. Service, Oak Ridge, Tenn.

Diment, W. H., and others, 1959a, Geological Survey investigations in the U12b.03 and U12b.04 tunnels, Nevada Test Site: U.S. Geol. Survey TEM-996, issued by U.S. Atomic Energy Comm. Tech. Inf. Service, Oak Ridge, Tenn. 1959b, Geological Survey investigations in the Ul2b.Ol tunnel, Nevada Test Site: U.S. Geol。Survey TEM-998, issued by U.S. Atomic Energy Comm. Tech. Inf. Service, Oak Ridge, Tenn. Gibbons, A. B., 1958, Geologic effects of the Rainier underground test, a preliminary report: U.S. Geol. Survey TEI-718, issued by U.S. Atomic Energy Comm. Tech. Inf。Service, Oak Ridge, Tenn. Gibbons, A. B., and others, 1960, Preliminary geologic map of the Tippipah Spring NW Quadrangle, Nye County, Nevada: U.S. Geol. Survey TEI-754, issued by U.S. Atomic Energy Comm. Tech. Inf. Service, Oak Ridge, Tenn.

Hansen, W. R., and Lemke, R. W., 1957, Geology of the USGS and Rainier tunnel areas, Nevada Test Site: U.S. Geol. Survey TEI-716, issued by U.S.Atomic Energy Comm.Tech. Inf.Service, Oak Ridge, Tenn. 
Hinrichs, E。 N., and Orkild, P。 P., 1961, Eight members of the Oak Spring Formation, Nevada Test Site and vicinity, Nye and Lincoln Counties, Nevada, in Short papers in the geologic and hydrologic sciences: U.S. Geol. Survey Prof. Paper 424-D, Art. 327 (in press). Mckeown, F. A., and Dickey, D. D., 1960, Some relations between geology and effects of underground nuclear explosions at Nevada Test Site, Nye County, Nevada, in Short papers in the geological sciences: U.S. Geol. Survey Prof. Paper 400-B, Art. 190, p. B415-B417. 1961, Interim report on geologic investigations of the U12e tunnel system, Nevada Test Site, Nye County, Nevada: U.S. Geol. Survey TEI-772, issued by U.S. Atomic Energy Comm. Tech. Inf. Service, Oak Ridge, Tenn.

Shapiro, Leonard, and Brannock, W. W., 1956, Rapid analysis of silicate rocks: U.S. Geol. Survey Bull. 1036-C, p. 19-56. 


